Article

\title{
Responding to Landscape Change: Stakeholder Participation and Social Capital in Five European Landscapes
}

\author{
Thanasis Kizos ${ }^{1, *}$, Tobias Plieninger ${ }^{2,3}$ (D), Theodoros Iosifides ${ }^{1}$, María García-Martín 4 ([), \\ Geneviève Girod ${ }^{5}$, Krista Karro ${ }^{6}$, Hannes Palang ${ }^{6}{ }^{(0)}$, Anu Printsmann ${ }^{6}$, Brian Shaw ${ }^{7}$, \\ Julianna Nagy $^{8}$ and Marie-Alice Budniok ${ }^{8}$ \\ 1 Department of Geography, University of the Aegean, University Hill, 81100 Mytilene, Greece; \\ iwsifidis@aegean.gr \\ 2 Faculty of Organic Agricultural Sciences, Steinstr. 19, 37213 Witzenhausen, University of Kassel, \\ Kassel 34125, Germany; plieninger@uni-kassel.de \\ 3 Department of Agricultural Economics and Rural Development, University of Göttingen, \\ Platz der Göttinger Sieben 5, 37073 Göttingen, Germany \\ 4 Chair of Nature Conservation and Landscape Ecology, University of Freiburg, Tennenbacher Str. 4, \\ 79106 Freiburg, Germany; maria.garcia@landespflege.uni-freiburg.de \\ 5 ALTICIME, 60 rue Joseph Desbois, 69330 Meyzieu, France; girod.cime@alticime.net \\ 6 Centre for Landscape and Culture, School of Humanities, Tallinn University, Uus-Sadama 5, 10120 Tallinn, \\ Estonia; kristak166@gmail.com (K.K.); palang@tlu.ee (H.P.); anu.printsmann@tlu.ee (A.P.) \\ 7 Chair of Societal Transition and Agriculture, University of Hohenheim, Schloss Museumsflügel Ost, \\ 70593 Stuttgart, Germany; Brian.shaw@landespflege.uni-freiburg.de \\ 8 European Landowners' Organization, Rue de Trèves 67, 1040 Brussels, Belgium; \\ julianna.nagy@elo.org (J.N.); legal@elo.org (M.-A.B.) \\ * Correspondence: akizos@aegean.gr; Tel.: +30-22510-36447
}

Received: 30 November 2017; Accepted: 17 January 2018; Published: 22 January 2018

\begin{abstract}
The concept of landscape has been increasingly used, in the last decades, in policy and land use planning, both in regard to so-called "special" and to "ordinary" or "everyday" landscapes. This has raised the importance of local and public participation in all issues that refer to landscapes and the definition of the groups that "have a stake" in the landscape. In this paper, we provide insights into how stakeholders perceive the dynamics of local processes of landscape change (and continuity) and which processes of landscape change they perceive as important, in positive and negative ways, from five communities within the European Union. These landscapes involve different landscape issues "at stake", different national and local planning and decision-making traditions and practices, and varying degrees of engagement. The understanding of these complexities and the unraveling of the insights is done through the concept of social capital and its different forms. We report on three series of workshops that have been organized to discuss landscape issues and approaches or ideas for landscape management. We witnessed interactions between the different stakeholders and gained insights into how social capital affects landscape change. We found that despite differences, similarities emerged concerning the interplay between "expert" and "local" knowledge and between "insideness" and "outsideness". Social capital plays an important part, as it provides the template for personal and collective evaluation of landscape changes, who should manage these changes and how they should be managed. These findings are important to develop in-depth insights on dynamics and values of cultural landscapes and visions for re-coupling social and ecological components in cultural landscapes and translate them into policy and management options.
\end{abstract}

Keywords: social capital; landscape change; stakeholder workshops; local knowledge 


\section{Introduction}

Landscape has been increasingly used in previous decades as a spatial level in policy and land use planning [1,2]. Landscapes are a fascinating boundary object for multiple disciplines as they are located "at the interface of nature and culture and express a tight interplay of physical features of the human environment with social structures and human ideas" ([3]; p. 2). The tight coupling of nature and culture in landscapes was recognized by the European Landscape Convention [4], which also called for increased recognition of "ordinary", "vernacular", or "everyday" landscapes and of the value of landscapes as parts of local identities and societal well-being [5]. Increased emphasis on the human dimensions of landscapes has raised the importance of local participation in all landscape issues, including land use planning and landscape management, and especially when landscape is understood as "a central arena for sustainable development" [3].

With participation becoming more important for the protection, management, and planning of landscapes, including rates and magnitudes of change of/in the landscape, it is necessary to define the different groups that "have a stake" in the landscape [6]. According to Howard [7], the following actor groups require consideration in landscape planning: (a) the owners of the land, with multiple roles as producers, landowners, and members of a community [8], for which, besides the cost of land and all types of economic activities, the cultural capital associated with it and place attachment should be considered; (b) governments at various levels; (c) visitors or tourists that look for recreation and experiences; (d) academics; (e) the media, who are typically interested in the visual element of the landscape and its "newsworthiness"; (f) groups with "special" interests, such as environmentalists, hunters, or hikers; and (g) "everyday users" /"insiders" (as opposed to "outsiders") who are intimate with the land and the landscape. Determinants such as gender, age, religion, culture, nationality, education, power/class, and economic activity make the actual mix of stakeholder groups even more complex.

Stakeholder participation has gained relevance through an increasing demand for high-quality amenity landscapes and through a general trend towards decentralized landscape planning and policy in many parts of the European Union. However, despite the growing recognition of the need to involve the public and a clear growth of bottom-up landscape stewardship initiatives [9], stakeholder participation has frequently been absent in landscape character assessments [10], landscape planning [11], landscape policy and landscape research [12]. Recently, García Martín et al., ([9]; p. 2) introduced the term "landscape values" to "describe the socio-cultural perception of landscape functions", following Brown et al.'s ([13]; p. 19) framing of ecosystem values to "contain both use and non-use values associated with ecosystems". Landscape values can be used to frame and understand how stakeholders perceive local processes of landscape change, and this paper-with the use of a "social capital" framework-aims to provide insight into this understanding. More specifically, we explore the following research questions in five European landscapes that involve different landscape change issues "at stake", different national/local planning and decision-making traditions and practices:

- Do landscapes change for stakeholders and if so, how and why?

- How do trust and cooperation influence landscape stewardship?

- What forms of knowledge are needed for landscape stewardship and what potential conflicts exist between different forms of knowledge?

\section{Conceptual Framework: Social Capital}

The concept of social capital has been introduced to help in the understanding of many important social issues, typically overlooked when discussing various models of individual or collective behaviors. Here, we follow Jones [14], who defines social capital as a multidimensional concept consisting of: (a) social trust (trust between individuals); (b) institutional trust (trust in institutions that exist in a community, such as the government and the justice system); (c) compliance with social norms 
(both formal and informal ones); and (d) participation in social networks (which refers to the activation of citizens in the context of social networks). Apart from these dimensions, an important aspect of social capital is the type of connections in trust networks, compliance, and participation. For this connectedness, three types have been identified as important for the networks-within, between, and beyond communities-called bonding, bridging, and linking types of social capital. Communities here may refer to groups within the area or to groups outside the area, nearby or not. Bonding social capital "describes the links between people with similar outlooks and objectives and is manifested in different types of groups at the local level" [15]. Bridging social capital describes "the capacity of groups to make links with others who may have different views, particularly across communities", and linking social capital "describes the ability of groups to engage vertically with external agencies, either to influence their policies or to draw on useful resources" (p. 633).

When applied to landscape research, social capital is also useful for understanding the formation and dynamics of landscape conceptualizations, values, and even governance options for different stakeholder groups. The interplay of physical features with the practices, ideas, and values that make up cultural landscapes [3] calls for the investigation of these often-diverging ideas and values. It may be useful to contrast ideas and values, as perceived by the different "local" stakeholder groups and the "expert" point of view [12], or by tracking how "expert" knowledge and ideas are translated into "local" beliefs and practices. There are many pathways for interactions, including how experts "teach" locals what is acceptable and unacceptable in landscape appearance and function, experts researching and/or studying "local" ways and "traditional" ecological knowledge, and then locals "learning" or "re-learning" from this corpus of studies [16]. At the same time, individuals or groups can often have multiple roles. These multiple interplays between these distinct levels are vital for understanding the successes and failures of management and policy instruments, across various spatial levels, in relation to local particularities. From the "expert" point of view, solutions and "good practices" need to be addressed, while from the "local" point of view, the level of engagement with different stakeholders needs to be discussed, along with local knowledge in landscape management that supplements successful examples or provides good practices.

\section{Cases and Method}

The study was performed in five landscapes within the European Union (Figure 1): Gera and Plomari, Lesvos Island, Greece (LES); Modbury, South West Devon, UK (DEV); Grand Parc Miribel Jonage, Rhône-Alpes area, France (GPMJ), Kodavere, Estonia (VOK), and Colmenar Viejo, Madrid Region, Spain (COL). These areas cover a wide variety of geographical spaces, from Northern to Southern Europe and from East to West, and span major environmental and land-use history gradients, with varying degrees of homogeneity and one or more specific issues at stake, including different processes and rates of landscape change [17]. They also involve different planning and decision-making traditions and practices. Our approach focused on a local scale, using either administrative and/or physical boundaries. Under the EU classification system, this corresponds to the LAU I (Local Administration Units, typically the Municipality level for most of the EU countries) or LAU II (typically the settlement level) administrative units. The selected areas range in size from 22 to $182 \mathrm{~km}^{2}$. Population sizes vary strongly, from 1500 to 40,000 inhabitants (except for GPMJ). Table 1 gives an overview, including their sizes, locations, dominant landscapes, and populations. 


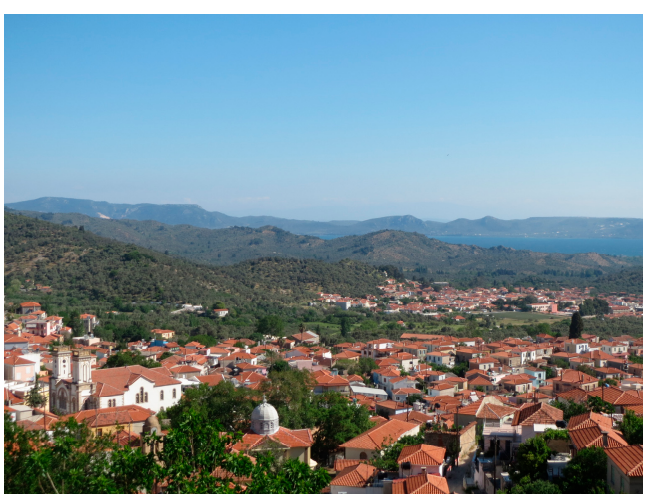

(A)

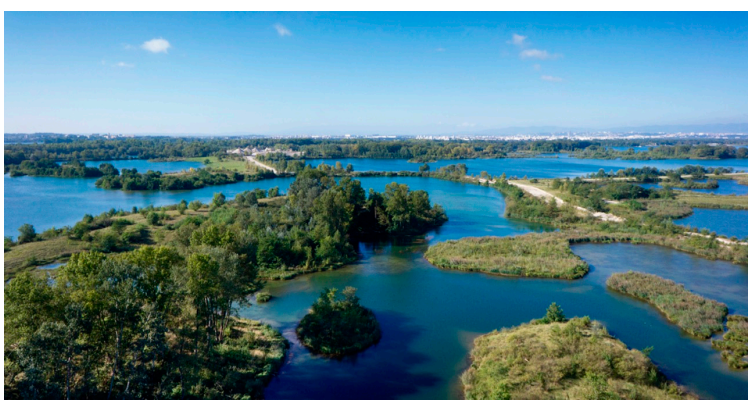

(C)

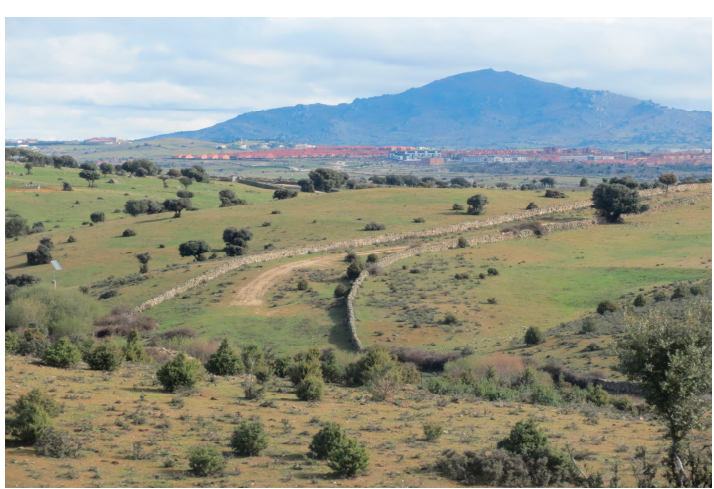

(E)

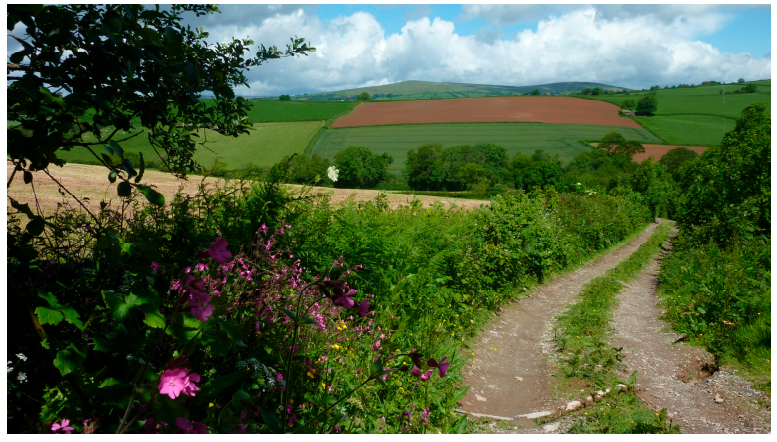

(B)

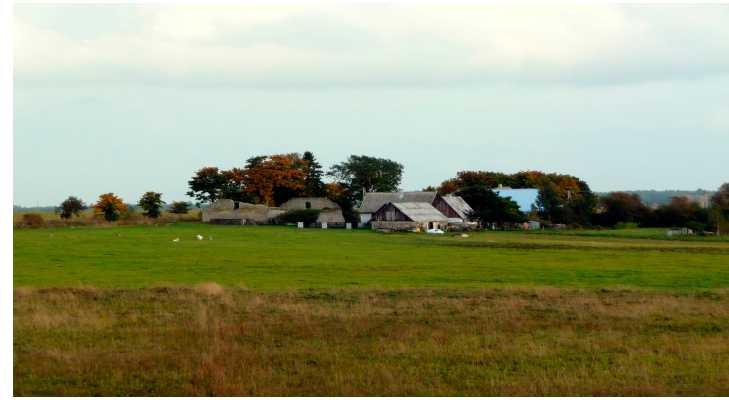

(D)

Figure 1. Typical landscapes in the case study areas. (A) Gera and Plomari; (B) Modbury; (C) Grand Parc Miribel Jonage; (D) Alatskivi and Peipsiääre, Vooremaa and Kodavere; (E) Colmenar Viejo.

Table 1. The case study areas and their landscapes.

\begin{tabular}{|c|c|c|c|c|c|}
\hline $\begin{array}{c}\text { Case Study } \\
\text { Area }\end{array}$ & $\begin{array}{c}\text { Area Size } \\
\left(\mathrm{km}^{2}\right)\end{array}$ & Population & Location & Land Uses, Landscape Features & Social Composition \\
\hline $\begin{array}{l}\text { Gera and } \\
\text { Plomari } \\
\text { (LES) }\end{array}$ & 87 & 11,700 & $\begin{array}{l}\text { At the foot of the } \\
\text { Olympus mountain } \\
\text { range on Lesvos } \\
\text { Island, Greece }\end{array}$ & $\begin{array}{l}\text { Hilly area with limestone and schist, } \\
\text { continuous olive plantations up to } \\
600 \mathrm{~m} \text { altitude (roughly } 80 \% \text { of } \\
\text { Utilized Agricultural Area and } 60 \% \\
\text { of the total area) and pine } \\
\text { forests-maquis. }\end{array}$ & $\begin{array}{l}\text { Most of the families in the area own } \\
\text { and manage olive plantations } \\
\text { part-time, the population is ageing } \\
\text { and fewer young people are willing } \\
\text { to engage professionally with } \\
\text { agriculture. }\end{array}$ \\
\hline $\begin{array}{l}\text { Modbury } \\
(\mathrm{DEV})\end{array}$ & 24 & 1500 & $\begin{array}{l}\text { In the Southwestern } \\
\text { part of Devon, UK }\end{array}$ & $\begin{array}{l}\text { Gently undulating with many small } \\
\text { rivers. Agriculture accounts for } 57 \% \\
\text { of the land (livestock farms of cattle } \\
\text { and sheep and mixed agriculture), } \\
\text { the rest for forestry, land used for } \\
\text { equestrian husbandry and sports, } \\
\text { hobby farming, etc. }\end{array}$ & $\begin{array}{l}\text { An area of gentrification, with older } \\
\text { residents being forced out of the } \\
\text { area due to the rising cost of land; } \\
\text { farming is a part-time activity. }\end{array}$ \\
\hline
\end{tabular}


Table 1. Cont.

\begin{tabular}{|c|c|c|c|c|c|}
\hline $\begin{array}{c}\text { Case Study } \\
\text { Area }\end{array}$ & $\begin{array}{c}\text { Area Size } \\
\left(\mathrm{km}^{2}\right)\end{array}$ & Population & Location & Land Uses, Landscape Features & Social Composition \\
\hline $\begin{array}{l}\text { Grand Parc } \\
\text { Miribel } \\
\text { Jonage } \\
\text { (GPMJ) }\end{array}$ & 22 & $\begin{array}{l}\text { 1,333,000 } \\
\text { (including } \\
\text { nearby } \\
\text { settlements) }\end{array}$ & $\begin{array}{l}\text { On the island of } \\
\text { Miribel-Jonage, in } \\
\text { the east of Lyon, in } \\
\text { Rhône-Alpes area, } \\
\text { France }\end{array}$ & $\begin{array}{l}\text { Level area, with river gravel soils, } \\
\text { nearly } 850 \text { ha of forest and } 450 \text { ha of } \\
\text { water surfaces. The main land uses } \\
\text { include gravel extraction, farming } \\
\text { ( } 400 \text { ha of farmland) and recreation } \\
\text { for residents. }\end{array}$ & $\begin{array}{l}\text { Farmers in the area have to face the } \\
\text { growing importance of } \\
\text { environmental conservation, the } \\
\text { area is also important for recreation } \\
\text { for the growing urban population }\end{array}$ \\
\hline $\begin{array}{l}\text { Kodavere, } \\
\text { (VOK) }\end{array}$ & 161 & 4000 & $\begin{array}{l}\text { On the Western } \\
\text { shores of Lake Peipsi, } \\
\text { in the eastern edge of } \\
\text { Estonia }\end{array}$ & $\begin{array}{l}\text { A plain of the coastal lowlands of } \\
\text { Lake Peipsi, the clayish-sandy } \\
\text { agricultural soils of the } \\
\text { Southeastern Estonian plain, and } \\
\text { relic land forms (elongated } \\
\text { drumlins) left by the regressing ice } \\
\text { cap. Habitation is sparse, in } \\
\text { dispersed town-like villages. }\end{array}$ & $\begin{array}{l}\text { The population consists of } \\
\text { Estonians, some of whom are } \\
\text { farmers, and Russians, and } \\
\text { attempts are being made to } \\
\text { reconcile land management and } \\
\text { cultural differences. }\end{array}$ \\
\hline $\begin{array}{l}\text { Colmenar } \\
\text { Viejo (COL) }\end{array}$ & 182 & 47,000 & $\begin{array}{l}\text { At the foothills of the } \\
\text { Sierra de } \\
\text { Guadarrama, } 30 \mathrm{~km} \\
\text { to the north of } \\
\text { Madrid, Spain }\end{array}$ & $\begin{array}{l}\text { Soft and irregular topography, hills } \\
\text { and shallow valleys. The main land } \\
\text { use is farming, with some areas } \\
\text { dominated by pastures with scarcer } \\
\text { trees (holm oak, Pyrenean oak, } \\
\text { prickly juniper, elm) and other areas } \\
\text { dominated by holm oak } \\
\text { wood-pastures. }\end{array}$ & $\begin{array}{l}\text { An area of high urbanization rates, } \\
\text { with many "newcomers" who come } \\
\text { with their own ideas of land } \\
\text { management and farming. }\end{array}$ \\
\hline
\end{tabular}

We used a deliberative approach to elicit stakeholders' perceptions of landscape change and explore their landscape values, through a series of workshops in each site. Deliberate approaches emphasize that landscape values are process and context-dependent, without claiming objectivity. Deliberative approaches are particularly useful for eliciting landscape issues, due to the inherent subjectivity of landscape values and the high level of interest that stakeholders have in them [18]. The approach also borrows from the conceptualization of landscapes by Jones [19] which uses a "scientific", an "applied", and a "humanistic" angle to describe how landscapes are regarded by different stakeholders.

Our deliberative approach followed three stages, in each of which a series of workshops were held in all areas. Potential stakeholders were identified and invited by local workshop organizers (who were partners of the EU project, HERCULES), but all workshops were also open to all to participate, with public announcements via posters. The approach was based on identifying different sets of landscape values (e.g., productive, ecological, aesthetic, historic, symbolic) and discussing and presenting ideas and practices for managing these values. Some of these practices-from local or expert knowledge or combinations-were selected to be "good landscape practices", reflecting different types of land management for each case study, according to local issues, including agriculture, livestock, recreation, and nature conservation on private-public land and rural-urban settings. Another purpose for performing three workshop rounds was to witness interactions between the different stakeholders and gain insight into the social capital in the area and how it affects landscape change, both in conceptualizing it (if and how the landscape "changes", if this type of change is good or bad, desirable or undesirable, etc.) and managing it.

In the first stage, introductory scoping workshops were performed, with the objective being to reveal the landscape issues that were important for local stakeholders in late winter and spring of 2015, in each area. Each workshop comprised an average of 30 participants, including different stakeholders, such as land owners, farmers (when these two groups were different), residents, local administration, experts, and local media. There were minor differences between the different areas with, for example, more experts in heritage conservation in VOK and more farmers in LES, but overall, the lists reveal similarities rather than differences. In a second stage, another round of workshops was conducted, in the fall of 2016, where the ideas and issues discussed in the first round were presented and revised, and a landscape management and governance approach was introduced. A third round of workshops was conducted in winter-spring 2016, to continue the second workshop themes and elaborate on strategies and social capital issues. The workshops were held in public meeting spaces, such as 
community halls, a museum, and town halls. Some of the events were videotaped or recorded and the material was translated into English by us. The selection of participants served another purpose, namely the investigation of different forms of social capital and its role in landscape preservation and change. This posed methodological issues for the different groups and areas, which were addressed with a broad common strategy that allowed for differentiations according to the theme and the particularities in the different areas. The overall strategy stressed the necessity of directly and indirectly investigating social and institutional trust, compliance with norms, and social networking, through observing and analyzing the dynamics of workshops and the content of them, in regard to the discourses of participants, their courses of action and practices, and their relationships with other participants. In the end, the findings were discussed and weighted against those from other areas in a meeting involving all workshop organizers.

\section{Insights}

\subsection{Common Issues—Processes and Differences}

The issues raised by stakeholders and workshop participants (see Table 2 where major issues are presented) were:

(a) Abandonment and preservation of the traditional management practices of olives in LES,

(b) Pressures of/on housing market, driven by high demand from "amenity migrants" in DEV,

(c) Diversity of co-existent activities mingled in GPMJ, such as local sustainable farming compatible with drinkable water protection

(d) Effectiveness of the preservation of natural, historical and cultural heritage (including linguistic) in VOK, and

(e) Processes of land and farming abandonment hand in hand with urban expansion and local population increase in COL.

One of the common issues that came up in all areas was abandonment and overgrowth of agricultural lands-olives in LES, arable farming in VOK and GPMJ, and animal farming in DEV and COL. As all these uses are considered valuable components of the local landscape and knowledge; abandonment was viewed very negatively. Loss of knowledge was attributed to the detachment of local actors from the land due to changed roles in landscape management, e.g., farmers having to cope with water preservation issues in GMPJ, farmers turning to hoteliers in LES, and to construction in DEV and COL, and farmers not being able to make a profit and abandoning the area in VOK. A characteristic example in COL was dry stonewalls-residents buying land for hunting and recreation use wire and concrete to fence their land, but expect farmers to maintain drystone walls for their aesthetic and ecological benefits.

Table 2. Main issues at stake, processes, and discussions in workshops.

\begin{tabular}{|c|c|}
\hline $\begin{array}{c}\text { Case Study } \\
\text { Area }\end{array}$ & Main Issues at Stake-Workshop Processes \\
\hline $\begin{array}{c}\text { Gera and } \\
\text { Plomari (LES) }\end{array}$ & $\begin{array}{l}\text { - Main issue that affects the landscape: land abandonment of olive } \\
\text { plantations (dominant land and farm use), linked with (a) gradual loss of } \\
\text { local knowledge; (b) low competitiveness in olive oil production, due to } \\
\text { sloping land and limited irrigation water availability. } \\
\text { Relatively high level of human capital available (quantity and quality) but } \\
\text { lacking interest in olive cultivation and landscape management } \\
\text { (pluri-activity dominant). } \\
\text { Very low level of trust towards presumabe clientelism (local and national) } \\
\text { government and farmer cooperatives. } \\
\text { One important initiative of social capital development through NGO 'Syn } \\
\text { tois allois' (translated as "with other people") that resulted in the social } \\
\text { enterprise MODOUSA (a local word meaning the olive tree that can } \\
\text { produce a modi of olives or roughly } 640 \mathrm{~kg} \text { ) displays that, despite the } \\
\text { distrust, there are opportunities for collective actions that seek to conserve } \\
\text { the landscape via productive olive fields. }\end{array}$ \\
\hline
\end{tabular}


Table 2. Cont.

\begin{tabular}{|c|c|}
\hline $\begin{array}{l}\text { Case Study } \\
\text { Area }\end{array}$ & Main Issues at Stake-Workshop Processes \\
\hline Modbury (DEV) & $\begin{array}{l}\text { - Main issue that affects the landscape: pressures of/on housing market, with } \\
\text { high demand for property, driven by 'amenity migrants', often } \\
\text { characterized by short-term occupancy and high impact on local economy. } \\
\text { Absence of bridging social capital between "newcomers" and older } \\
\text { residents; locals decried a lack of participation of migrants in local } \\
\text { associations and social groups and local development plans. } \\
\text { Hedgerow and farmland management is also an issue. There is } \\
\text { overwhelming support for farmers in workshops and their contribution to } \\
\text { the local landscape, people acknowledged that they have a responsibility, } \\
\text { themselves, to pay for the landscape by buying local food and going to } \\
\text { farmers' markets, but at the same time when asked to define future } \\
\text { landscape goals, they suggested subsidies and regulations. }\end{array}$ \\
\hline $\begin{array}{l}\text { Grand Parc } \\
\text { Miribel Jonage } \\
\text { (GPMJ) }\end{array}$ & $\begin{array}{l}\text { - Main issue that affects the landscape: presence of many different and } \\
\text { co-existent activities, such as recreation, drinking water and flooding } \\
\text { reserves, farming and gravel-extraction activities (declining, depriving } \\
\text { resources used for supporting landscape and biodiversity related activities). } \\
\text { Social networking, social capital, and collective action mentality and } \\
\text { practice, strengthened through an institutional organization that manages } \\
\text { GPMJ. It connects } 16 \text { communities and entertains relationships with } \\
\text { stakeholders, acting as a social capital and trust enhancer; is part of } \\
\text { a peri-urban park network and acts as a land owner that leases land } \\
\text { to farmers. } \\
\text { Social capital proved crucial during the development of a long-term vision } \\
\text { for the local environment (Vision for 2030), including more leisure activities } \\
\text { for city dwellers, improvement of pedestrian/bike/collective transportation } \\
\text { accessibility and a reduction in car accessibility, promotion of landscape as } \\
\text { "common good", and engaging farmers into labeling local quality products. }\end{array}$ \\
\hline $\begin{array}{l}\text { Kodavere, } \\
\text { (VOK) }\end{array}$ & $\begin{array}{l}\text { - Main issue that affects the landscape: the effectiveness of preservation of } \\
\text { natural, historical, and cultural heritage. There are three different cultural } \\
\text { heritage aspects: (a) Estonian (peasant), including speakers of a local dialect; } \\
\text { (b) Baltic German, mainly manor owners and their heirs; and (c) Russian } \\
\text { Old Believers. Cooperation is not easy, some positive examples include an } \\
\text { initiative called "The Onion Route", with a motto "One region, two nations, } \\
\text { three cultures". } \\
\text { Many landowners find legal heritage framework "too restrictive" for land } \\
\text { management. Especially valued are land and activities related with the } \\
\text { open land, which refers to the independence period of the 1920s-1930s } \\
\text { before nationalization. } \\
\text { Great emphasis on the preservation of the cultural landscape, including the } \\
\text { promotion and support of the local dialect (Kodavere). In general, } \\
\text { participants appeared to care deeply about their landscapes, heritage } \\
\text { mapping, excursions, old dispersed farmsteads, and historical monuments. }\end{array}$ \\
\hline $\begin{array}{l}\text { Colmenar Viejo } \\
\text { (COL) }\end{array}$ & $\begin{array}{l}\text { - Main issues that affect the landscape: processes of land and farming } \\
\text { abandonment and "rewilding", new infrastructure (roads), and the extreme } \\
\text { increase of local population, due to urban expansion. } \\
\text { Widespread distrust for central and local institutions decreases engagement } \\
\text { with collective initiatives towards landscape protection, e.g., conflicts } \\
\text { between local and regional administrations about the management of local } \\
\text { natural resources and heritage. Also, there is distrust and conflict between } \\
\text { local groups (farmers, hunters and landless villagers, or between old } \\
\text { residents and newcomers). } \\
\text { Lack of bridging social capital associated with strong ties among groups } \\
\text { with the same interests, e.g., how to protect dry stonewalls. All these lead to } \\
\text { very pessimistic outlooks on the future from older people. }\end{array}$ \\
\hline
\end{tabular}

Another common theme in most areas was "cultural landscapes versus (new) infrastructure". In GPMJ, COL, DEV, and to a lesser degree LES, the issue was discussed, in detail, as a threat to cultural landscapes. Although many locals in GPMJ, LES, and COL seemed to be in favor of transport, mobility, and access to the landscape, all agreed that such linear infrastructures can fundamentally change a landscape. A balance is sought between fast infrastructures crossing the landscape with no local use and "human size" ones that can link neighbor territories and improve accessibility.

Another common theme, concerning agriculture, was the integration of intensive agriculture into cultural landscapes. Unlike abandonment, intensive agriculture was brought into the discussion by the "experts", since it is a key factor in shaping the visual features of rural areas and a current trend in 
many areas of Europe, including COL, parts of LES, and DEV. Topics of discussion included trade-offs and the relationship between intensification and multifunctional land use.

The last issue that was widely discussed in the workshops was the role of heritage in cultural landscapes. Many layers of heritage are interwoven into landscapes, and discussions revolved around historical and archaeological heritage (LES, VOK, DEV) and protection, along with other land management practices, including agriculture (GPMJ), meeting places for the sense of community and identity (in all areas), local knowledge (again all areas, linked with the abandonment theme), and intangible heritage (VOK, where a local dialect was considered an important aspect of the landscape). This is in line with the results of a study conducted in the same areas ([9], except GPMJ), where residents were asked to map the places where they perceived a set of landscape values. In this study, cultural heritage elements played an important role in the perception of other values, mainly connected to sense of community and identity. Agriculture abandonment was not prominent among the landscapes or the changes mentioned by the respondents.

The comparison of these perceived changes in relation to the changes detected with the use of historical maps and satellite images in the case study areas in the last 100 to 150 years ([17], GPMJ was not included), reveals that despite differences between the areas, settlements and forests increased everywhere, indicating that indeed urbanization and abandonment seemed to be the most important processes of change. The second most important was afforestation, followed by expansion and intensification of agriculture. These processes were the result of conversion of cropland to grassland, especially in COL and LES, and of the expansion of forests in all areas. Rates were higher in COL, followed by LES and VOK, while DEV was the most stable landscape. These findings seem to be in line with what the respondents reported in the workshops, but also with a pan-European analysis of the twentieth century [20].

Finally, the findings of the workshops can be compared with cultural ecosystem services and landscape features from social media pictures for three of the areas (COL, LES, and VOK, [21]). Terrestrial (and marine in LES) recreation dominated the picture themes, with differences between the areas that reflect the presence of the sea or lake, in LES and VOK, respectively, while trees, infrastructures, grasslands, and waterbodies were the landscape features more frequently depicted. Despite the importance of agriculture in all workshop themes, surprisingly few pictures included agricultural features and this seems to be the major discrepancy between services depicted and the opinions of stakeholders.

\subsection{Trust and Cooperation}

In our workshops, attendance differed in who chose to come and who refrained. Not all previously identified stakeholder groups attended in all areas, and even those that did, questioned the practical impact of these workshops. We attempted to contact some of these groups to invite them to the remaining workshops, and enquire the reasons for not attending. Although mostly practical reasons were offered (lack of time, other arrangements), it seems that at times, the attendance of other stakeholders was inhibiting, or they were simply not interested in what was being discussed. A reason offered by those who came was the lack of trust that undermines participation and cooperation. Thus, in those cases, relatively low social/institutional trust and reluctance to engage with social and institutional networks was indicated by the participation turnout. Moreover, in LES, participation turnout indicated that trust towards collective initiatives is very low, due to negative local experiences with cooperatives, and this was reported as a disincentive for attending the workshops. Only a bottom up initiative that emerged out of the failure of former cooperatives to provide farmers with better prices and collective bargaining position, MODOUSA, played a pivotal role in the workshops; however, at the same time, it seems that farmers and other locals, who, for personal or business reasons, did not respond positively to it, were discouraged to participate. This came in sharp contrast with GPMJ, where the "facilitating" role of the GPMJ organization seemed to be very important for bringing together different types of farmers and related associations and other local representatives (elected or experts). 
As Conrad et al., ([1]; p. 2097) suggest, "Existing landscape research has been heavily limited in the extent to which it involves stakeholders or develops innovative methods for doing so". Our workshops indicate that the task of stakeholder involvement and understanding is central when it comes to landscape management (see also [22]). Collaboration has been both one of the weakest and one of the strongest points that came up during the workshops, sometimes even within the same area, as in LES with the social cooperative on one hand and the lack of cooperation from all the other stakeholders. As Pretty and Smith ([15]; p. 633) put it, "relations of trust lubricate cooperation", but trust takes time to build and is easily broken and "when a society is pervaded by distrust or conflict, cooperative arrangements are unlikely to emerge". Trust, according to [23], is also facilitated when governance is built on a dialogue, independent from particular planning "calendars".

One needs not being overoptimistic about the effect of local trust and connectedness. Some societies are based on fear and power [15], while rules and norms can also trap people within harmful social arrangements. In those cases, genuine social and institutional trust is absent, due to the existence and proliferation of domineering relations among social groups and various institutions. A typical example was discussed in VOK, regarding different heritages from three local cultural groups: the architectural heritage of the Baltic German noblemen (still very visible, see also [24]), the Estonian-speaking farmers (with a local dialect), and Russian-speaking old-believers (the most closed group of these three). Although the local dialect was considered a flagship example during the workshops, being one of the symbols of the area these days, it remains to be seen whether this blending, theoretically based on cooperation and understanding, will homogenize these groups in the future. On the other hand, local heritage (tangible and intangible) in COL is potentially important for an agreement between the different stakeholder groups and institutions and for building trust. It was noticed that even though tensions and distrust initially arose when the topic of local heritage protection was brought up by an "outsider" (expert or not), eventually all groups revealed strong attachment and interest in managing the land for its preservation.

\subsection{Local Knowledge and Knowledge Transfer}

Traditional ecological knowledge transfer is another issue of importance, which caused vivid discussions. In the past, knowledge was transferred and managed within local societies. For the participants in the workshops, this knowledge has been largely replaced by formal knowledge, transferred and managed by experts (agronomists, farm consultants, etc.). This knowledge has claimed high legitimacy in identifying problems in farming practices and prescribing solutions, but at the same time, and in many cases, it is conceptualized as a knowledge which derives from power and domineering relations and not from social and institutional relations characterized by trust. An issue raised in LES, regarding expert knowledge, concerned the different strands of such knowledge availability, for example, practices for management of olive trees and fields that were brandished as "scientific" in the recent past (e.g., certain pruning practices of high side branches and late collection of olives to ensure higher olive oil content and waiting up to three days before milling). Such practices are now considered non-relevant or even harmful for the quality of olive oil (pruning side branches differently and early collection is favored and milling has to be done in the same day). Stakeholders expressed some concerns on the issue of the ever-changing perceptions and prescriptions ("and what tells us that this [the management protocol presented] will not change again in a couple of years?" was a typical remark). This may nevertheless represent a case of path dependency on the side of farmers, as documented in other similar cases [25]. In GPMJ, knowledge transfer is more a matter of educating city residents-people with no "farming roots" — to respect farmlands and farmers' labor. Another one is to have the youth connect food to the land, and understand food provisioning issues. In VOK, the same was discussed for slash-and-burn farming, which was practiced in the fringes of the forest before the socialist transition. Once a common land management practice in many parts of Europe, it is now illegal for presumably environmental reasons, but according to local TEK, it remains 
a natural way of controlling pests [24]. Again, this can be considered an example of a path dependency case, with societal demands rendering a local practice obsolete.

For informal, local knowledge, another important tension, in terms of social capital, is the tension between "newcomers" and "old residents". In all the case study landscapes, a bigger or smaller part of the population is either comprised by "newcomers" or with locals that have been disassociated with the use of local and informal knowledge on land management. Therefore, local knowledge may survive in fragments or be based on expert knowledge. Sometimes, for example, in VOK, those who are more committed to the preservation of cultural heritage are not people who have been born there, but people who have moved there at some point in their life. In COL, the situation is similar, with many newcomers being more active in local traditions (this does not stop them from being considered outsiders even if they have been living there for decades and similar issues were reported in VOK as well) than long-established families. Newcomers seem also to be more sensitive to environmental heritage and biodiversity in general.

\section{Conclusions}

Despite the variety of socio-ecological characteristics in the five European landscapes studied in this paper, and the different discussions in the 15 workshops, a social capital approach toward conceptualizing landscape stewardship allows some general conclusions.

First, the combination of strong bonding social capital (strong networking and ties within groups with the same interests and/or views) and weak bridging social capital (widespread distrust between different social actors and groups) often prevents engagement with broader and longer term collective initiatives for environmental protection and landscape stewardship. The degree of rurality/urbanity seems to be decisive, as in peri-urban areas (e.g., in COL) bonding ties are less strong, while the diversity of residents favors bridging and networking. This raises the issue of how strengthening forms of bridging social capital, networking and trust can be encouraged and achieved.

Second, institutional social capital is weak in many of the European landscapes studied. Widespread distrust is paralyzing the relationships of local societies and key institutions, e.g., cooperatives in some areas and especially local and regional administrative and planning structures. At the same time, the administrative capacity at the local/regional level may be an important factor that needs to be taken into account when addressing landscape management issues. This was a central part of our approach, as we focused more on informal links and networks. However, effective landscape stewardship depends on such cross-sectoral and cross-scale linkages, as landscapes are interfaces between distinct functions, sectors, and scales.

Third, local knowledge about rallying stakeholders and actors matters for landscape stewardship, including conceptualizing and managing landscape change and conservation. This is an important lesson for designing and implementing landscape-related bottom up approaches-respecting and highlighting such practices and knowledge and combining them in a meaningful way with "expert", scientific knowledge will work better than relying in scientific knowledge solely.

Fourth, conflicts of interests between various local groups and actors arise in many cases, raising concerns about the "proper" way of combining environmental protection with local development strategies through landscape stewardship. The development of a culture of general trust and cooperation towards achieving more sustainable practices and a general commitment in deliberating conflict-resolution practices seems to be fruitful for "positive" change.

Acknowledgments: The research leading to these results has received funding from the European Community's Seventh Framework Programme under Grant Agreement No. 603447 (Project HERCULES). The funding source is not involved in study design; in the collection, analysis, and interpretation of data; in the writing of the report; and in the decision to submit the article for publication. The research reported in this paper contributes to the Global Land Programme (https://glp.earth) and the Programme on Ecosystem Change and Society (http://www.pecs-science.org).

Author Contributions: Thanasis Kizos, Tobias Plieninger, María García-Martín, Geneviève Girod, Hannes Palang, Anu Printsmann, Julianna Nagy and Marie-Alice Budniok conceived the original idea; Thanasis Kizos, 
María García-Martín, Geneviève Girod, Krista Karro, Hannes Palang, Anu Printsmann, Brian Shaw, Julianna Nagy and Marie-Alice Budniok participated in the workshops; Thanasis Kizos, Tobias Plieninger, Theodoros Iosifides analyzed the data; Thanasis Kizos, Tobias Plieninger, Theodoros Iosifides, wrote the paper with contributions from María García-Martín, Geneviève Girod, Krista Karro, Hannes Palang, Anu Printsmann, Brian Shaw, Julianna Nagy and Marie-Alice Budniok.

Conflicts of Interest: The authors declare no conflict of interest.

\section{References}

1. Conrad, E.; Christie, M.; Fazey, I. Is research keeping up with changes in landscape policy? A review of the literature. J. Environ. Manag. 2011, 92, 2097-2108. [CrossRef] [PubMed]

2. Sayer, J.; Sunderland, T.; Ghazoul, J.; Pfund, J.L.; Sheil, D.; Meijaard, E.; Venter, M.; Boedhihartono, A.K.; Day, M.; Garcia, C.; et al. Ten principles for a landscape approach to reconciling agriculture, conservation, and other competing land uses. Proc. Natl. Acad. Sci. USA 2013, 110, 8349-8356. [CrossRef] [PubMed]

3. Plieninger, T.; Kizos, T.; Bieling, C.; Le Dû-Blayo, L.; Budniok, M.-A.; Bürgi, M.; Crumley, C.L.; Girod, G.; Howard, P.; Kolen, J.; et al. Exploring ecosystem-change and society through a landscape lens: recent progress in European landscape research. Ecol. Soc. 2015, 20, 5. [CrossRef]

4. Council of Europe. European Landscape Convention. ETS No.176. 2000. Available online: http:/ / conventions.coe. int/Treaty/en/Treaties/Html/176.htm (accessed on 18 June 2017).

5. Jones, M.; Howard, P.; Olwig, K.R.; Primdahl, J.; Sarlöv-Herlin, I. Multiple interfaces of the European landscape convention. Norsk Geografisk Tidsskrift-Nor. J. Geogr. 2007, 61, 207-215. [CrossRef]

6. Reed, M.S.; Graves, A.; Dandy, N.; Posthumus, H.; Hubacek, K.; Morris, J.; Prell, C.; Quinn, C.H.; Stringer, L.C. Who's in and why? A typology of stakeholder analysis methods for natural resource management. J. Environ. Manag. 2009, 90, 1933-1949. [CrossRef] [PubMed]

7. Howard, P.J. An Introduction to Landscape; Ashgate: Farnham, UK, 2011.

8. Primdahl, J.; Kristensen, L.; Busck, A.G. The farmer and landscape management: Different roles, different policy approaches. Geogr. Compass 2013, 7. [CrossRef]

9. Garcia-Martin, M.; Fagerholm, N.; Bieling, C.; Gounaridis, D.; Kizos, T.; Printsmann, A.; Muller, M.; Lieskovsky, J.; Plieninger, T. Participatory mapping of landscape values in a Pan-European perspective. Landsc. Ecol. 2017, 32, 2133-2150. [CrossRef]

10. Butler, A.; Berglund, U. Landscape Character Assessment as an Approach to Understanding Public Interests within the European Landscape Convention. Landsc. Res. 2012, 39, 219-236. [CrossRef]

11. De Montis, A. Measuring the performance of planning: the conformance of Italian landscape planning practices with the European Landscape Convention. Eur. Plan. Stud. 2016, 24, 1727-1745. [CrossRef]

12. Conrad, E.; Cassar, L.F.; Jones, M.; Eiter, S.; Izaovi ová, Z.; Barankova, Z.; Christie, M.; Fazey, I. Rhetoric and reporting of public participation in landscape policy. J. Environ. Policy Plan. 2011, 13, 23-47. [CrossRef]

13. Brown, G.; Hausner, V.H.; Lagreid, E. Physical landscape associations with mapped ecosystem values with implications for spatial value transfer: An empirical study from Norway. Ecosyst. Serv. 2015, 15, 19-34. [CrossRef]

14. Jones, N. Investigating the influence of social costs and benefits of environmental policies through social capital theory. Policy Sci. 2010, 43, 229-244. [CrossRef]

15. Pretty, J.; Smith, D. Social capital in biodiversity conservation and management. Conserv. Biol. 2004, 18, 631-638. [CrossRef]

16. Palang, H.; Alumäe, H.; Printsmann, A.; Rehema, M.; Sepp, K.; Sooväli-Sepping, H. Social landscape: Ten years of planning 'valuable landscapes' in Estonia. Land Use Policy 2011, 28, 19-25. [CrossRef]

17. Bürgi, M.; Bieling, C.; von Hackwitz, K.; Kizos, T.; Lieskovsky, J.; Garcıa Martin, M.; McCarthy, S.; Muller, M.; Palang, H.; Plieninger, T.; et al. Processes and driving forces in changing cultural landscapes across Europe. Landsc. Ecol. 2017, 32, 2097-2112. [CrossRef]

18. Raymond, C.M.; Kenter, J.O.; Plieninger, T.; Turner, N.J.; Alexander, K.A. Comparing instrumental and deliberative paradigms underpinning the assessment of social values for cultural ecosystem services. Ecological Economics 2014, 107, 145-156. [CrossRef]

19. Jones, M. The elusive reality of landscape. Concepts and approaches in landscape research. Norsk Geografisk Tidsskrift-Nor. J. Geogr. 1991, 45, 229-244. [CrossRef] 
20. Fuchs, R.; Herold, M.; Verburg, P.H.; Clevers, J.G.P.W.; Eberle, J. Gross changes in reconstructions of historic land cover/use for Europe between 1900 and 2010. Glob. Chang. Biol. 2015, 21, 299-313. [CrossRef] [PubMed]

21. Oteros-Rozas, E.; Martín-López, B.; Fagerholm, N.; Bieling, C.; Plieninger, T. Using social media photos to explore the relation between cultural ecosystem services and landscape features across five European sites. Ecol. Indic. 2017. [CrossRef]

22. Prager, K. Agri-environmental collaboratives for landscape management in Europe. Curr. Opin. Environ. Sustain. 2015, 12, 59-66. [CrossRef]

23. Lazzeri, Y. Paysage, Développement Durable et Participation Citoyenne. In Biodiversité, Paysage et Cadre de Vie, La Démocratie en Pratique; Luginbühl, Y., Ed.; Victoire Editions: Paris, France, 2015; pp. 111-120.

24. Viik, T.; Kaljundi, L.; Printsmann, A.; Palang, H. Sustainability through Alteration: Eastern Baltic manors in the Estonian tradition. In Theory and Practice in Heritage and Sustainability: Between Past and Future; Auclair, E., Fairclough, G., Eds.; Routledge: New York, NY, USA, 2015; pp. 147-160.

25. Wilson, G.A.; Kelly, C.L.; Briassoulis, H.; Ferrara, A.; Quaranta, G.; Salvia, R.; Detsis, V.; Curfs, M.; Cerda, A.; El-Aich, A.; et al. Social memory and the resilience of communities affected by land degradation: Social memory, resilience and land degradation. Land Degrad. Dev. 2017, 28, 383-400. [CrossRef]

(C) 2018 by the authors. Licensee MDPI, Basel, Switzerland. This article is an open access article distributed under the terms and conditions of the Creative Commons Attribution (CC BY) license (http:/ / creativecommons.org/licenses/by/4.0/). 